\title{
Synthesis and Anticancer Activity of Some New Derivatives of Coumarin and Quinolinyl Mercaptotriazoles
}

\author{
MONA A. HOSNY*, HYAM A. RADWAN, AND EMTITHAL A. EL-SAWI \\ Department of Chemistry, Faculty of Women for Arts \\ Science and Education, Ain Shams University, Cairo, Egypt
}

Received 4 August 2011; Accepted 19 October 2011

\begin{abstract}
Pechmann condensation of ethylacetoacetate with derivatives of phenol by heating in absence of solvent and with montmorillonite clays K-10 afforded coumarin derivatives (1a-e) in good yields which on reaction with thiosemicarbazide in anhydrous pyridine yielded coumarin-quinolinyl mercaptotriazole (2a-e). The latter compounds were evaluated for their antimicrobial and anticancer activities. The newly synthesized compounds were characterized by IR, ${ }^{1} \mathrm{HNMR}$ and mass spectra.
\end{abstract}

Keywords: Coumarin, Mercaptotriazole, Thiol.

\section{Introduction}

In the past decades, the problem of multidrug resistant microorganisms has reached on alarming level around the world, and the synthesis of new anti-infective compounds has become an urgent need for the treatment of microbial infections. The 1, 2, 4-triazole nucleus has been incorporated into a wide variety of therapeutically important agents ${ }^{1}$, mainly displaying anti-microbial ${ }^{2-5}$ anti inflammatory activities ${ }^{6-9}$. On the other hand a new class of mercapto 1, 2, 4-triazole were submitted ${ }^{10}$ and were indicated powerful pharmacological activities. ${ }^{11}$ In view of these findings, and in continuation to our interest in the synthesis and biological activities 1, 2, 4 triazole $^{12}$. There have been many synthetic routes to the coumarins including the Pechmann ${ }^{13}$, Perkin $^{14}$, Knoevenagel ${ }^{15,16}$, Reformatsky ${ }^{17}$ and Witting $^{18,19}$ reactions. The present investigation describes the synthesis as potential antimicrobial agents of new series of mercapto 1, 2, 4-triazole were certain coumarin and quinolinyl mercaptotriazoles derivatives are remarkably effective compounds both with respect to their bioactivity of certain pharmacological activities regulating effect as well as 
anticancer activity. Montmorillonite clays have been used as efficient catalysts for a variety of organic reactions ${ }^{20}$. They are inexpensive non toxic powders which can be filtered easily from reaction mixtures and may be reused. In connection with our work on montmorillonite clays catalyses $^{21,22}$. We describe an environmentally friendly procedure for the synthesis of coumarins via Pechman reaction catalysed by montmorillonite K-10.

\section{Experimental}

Melting points were taken on Gallen kamp melting point apparatus and were uncorrected. Thin layer chromatography was performed with fluorescent silica gel plates $\mathrm{HF}_{254}$ (Merck), and plates were viewed under $\mathrm{UV}_{254}$ and 265 light. Infrared spectra $\left(\lambda-\mathrm{cm}^{-1}\right)$ were recorded on Bruker vector Germany and on Mattson FT-IR 1000, using KBr disks, mass spectra are measured on GCQ Finnigan MAT and ${ }^{1}$ H-NMR spectra were recorded on Gemini-200 MHZ NMR spectrometer in DMSO- $\mathrm{d}_{6}$ spectra were internally referenced to TMS. Peaks are reported in ppm. Downfield of TMS. The antibacterial activity was determined in microanalytical center Cairo University and anticancer activity was done in National Cancer Institute, Cancer Biology Department, Pharmacology, Cairo University. Different phenols, ethyl aceto acetate and thiosemicarbazide were obtained from Fluka or Aldrich.

\section{Syntheses}

\section{General Procedure for Compound (1a-e)}

A mixture of phenolic compound 1 (5 mmol) and ethylaceto acetate $(5 \mathrm{mmol})$ and montmorillonite K-10 (30 wt \% to 1 and ethylacetoacetate) was heated at $150{ }^{\circ} \mathrm{C}$ for those reactions in the absence of solvent with constant stirring for 12 hours. The montmorillonite was filtered off and washed with hot ethanol. The solvent was removed under reduced pressure to afford the new product. The crude product was purified and crystallized from ethanol to give the pure related coumarin (1a-e) as in (scheme 1).

\section{General Procedure for Compounds (2a-e)}

Compound $\mathbf{2 a}$ or $\mathbf{2 b}$ or $\ldots . . \rightarrow \mathbf{2 e}(0.2 \mathrm{~mol})$ and thiosemicarbazide $(0.2 \mathrm{~mol})$ in anhydrous pyridine $(50 \mathrm{~mL})$ was tested under reflux for $2 \mathrm{~h}$. Subsequently, the reaction mixture was poured into crushed ice containing concentrated hydrochloric acid $(10 \mathrm{~mL})$. A dark brown solid separated out and was left for $1 \mathrm{~h}$, then filtered, washed, dried and crystallized from methanol to give the pure related quinolinyl mercaptotriazoles (2a-e), as in (Scheme 1). 


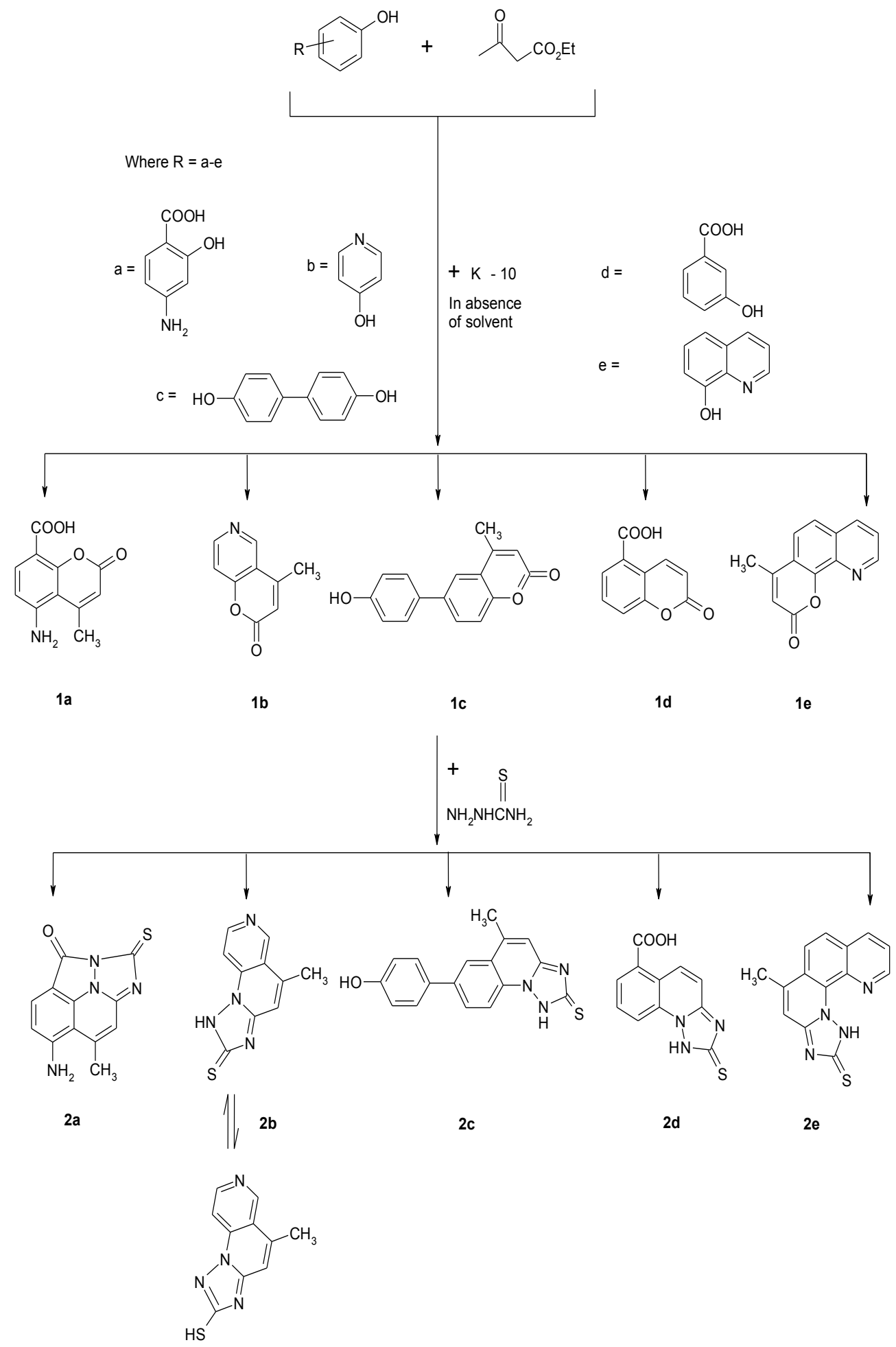

Scheme 1. Synthesis of coumarin from phenolic compounds with ethylaceto acetate catalyzed by 
montmorillonite.

Characterization data of coumarine derivatives (1a-e) and coumarin-quinolinyl mercaptotriazole (2a-e)

Compound 1a: Deep brown solid, (yield: $70 \%)$, mp 151-153 ${ }^{\circ} \mathrm{C}$. IR $(\mathrm{KBr})\left(\mathrm{cm}^{-1}\right): \mathrm{v}:, 3485-$ $3200\left(\mathrm{NH}_{2}\right), 3134(\mathrm{OH}$-carboxylic acid), $3049(\mathrm{ArC}-\mathrm{H}), 1710,1685(\mathrm{C}=\mathrm{O}) ; \mathrm{MS}(\mathrm{m} / \mathrm{z} \%): 219$ (9.53\%), 175 (100\%); ${ }^{1} \mathrm{H}-\mathrm{NMR},\left(\mathrm{DMSO}_{6} \mathrm{~d}_{6}\right) \delta: 11.4(1 \mathrm{H}, \mathrm{COOH}), 6.4-7.41(2 \mathrm{H}, \mathrm{Ar}), 5.9$ $(1 \mathrm{H},=\mathrm{CH}-\mathrm{C}=\mathrm{O}), 3.8\left(2 \mathrm{H}, \mathrm{NH}_{2}\right), 2.17\left(3 \mathrm{H}, \mathrm{CH}_{3}\right)$.

Compound 1b: Brown solid, (yield: $83 \%), \mathrm{mp} 55-56{ }^{\circ} \mathrm{C}$. IR $(\mathrm{KBr})\left(\mathrm{cm}^{-1}\right): \mathrm{v}: 3061(\mathrm{Ar}-\mathrm{CH}$ Str), 2858 (aliphaticCHstr.), $1685(\mathrm{C}=\mathrm{O}), 1544(\mathrm{C}=\mathrm{N}), 1382$ (C-H bend.); MS (m/z \%): 123 (68.63\%), 95 (100\%); ${ }^{1} \mathrm{H}-\mathrm{NMR},\left(\mathrm{DMSO}_{6}\right)$ 8: 8.4- 7.7 (3H, Ar), $6.19(1 \mathrm{H},=\mathrm{CH}-\mathrm{C}=\mathrm{O}), 2.1$ $\left(3 \mathrm{H}, \mathrm{CH}_{3}\right)$.

Compound 1c: Pale Bage solid, (yield $86 \%), \mathrm{mp} 275^{\circ} \mathrm{C}$. IR $(\mathrm{KBr})\left(\mathrm{cm}^{-1}\right): \mathrm{v}: 3390(\mathrm{OH})$, 2925 (aliphaticCHstr.), $1733(\mathrm{C}=\mathrm{O}), 1609(\mathrm{C}=\mathrm{C}), 1474(\mathrm{C}-\mathrm{H}$ bend); $\mathrm{MS}(\mathrm{m} / \mathrm{z} \%): 252$ (0.4\%), $186(100 \%) ;{ }^{1} \mathrm{H}-\mathrm{NMR}\left(\mathrm{DMSO}_{6} \mathrm{~d} / 8.39-6.79(7 \mathrm{H}, \mathrm{Ar}), 5.60\right.$ (C-OH, Ar)6.1 $(1 \mathrm{H},=\mathrm{CH}-\mathrm{C}=\mathrm{O}), 1.29\left(3 \mathrm{H}, \mathrm{CH}_{3}\right)$.

Compound 1d: Brown solid, (yield: $79 \%), \mathrm{mp} 183-185^{\circ} \mathrm{C}$. IR $(\mathrm{KBr})\left(\mathrm{cm}^{-1}\right)$ : v: $3288(\mathrm{OH}-$ carboxylic acid), $1713(\mathrm{C}=\mathrm{O}), 1601(\mathrm{Ar} \mathrm{C}=\mathrm{C}) ; \mathrm{MS}(\mathrm{m} / \mathrm{z} \%): 190(0.09 \%), 121(100 \%) ;{ }^{1} \mathrm{H}-$ NMR (DMSO-d $\left.)_{6}\right) \delta: 10(1 \mathrm{H}, \mathrm{COOH}), 7.86-6.9(5 \mathrm{H}, \mathrm{Ar}),(1 \mathrm{H},=\mathrm{CH}-\mathrm{C}=\mathrm{O})$

Compound 1e: Brown solid (yield: $85 \%), \mathrm{mp} 65-67^{\circ} \mathrm{C}$. IR $(\mathrm{KBr})\left(\mathrm{cm}^{-1}\right): \mathrm{v}: 3047(\mathrm{ArCH})$, 3020,2975-2850 (aliphaticCHst.), $1730(\mathrm{C}=\mathrm{O}), 1592(\mathrm{C}=\mathrm{N}), 1600(\mathrm{Ar} \mathrm{C}=\mathrm{C}), 1433(\mathrm{C}-\mathrm{H}$ bend); MS (m/z\%): 211 (25\%), $186(100 \%) ;{ }^{1} \mathrm{H}-\mathrm{NMR}$ (DMSO-d $\left.\mathrm{d}_{6}\right) \delta: 8.84-7.53(5 \mathrm{H}, \mathrm{Ar})$, $6.2(1 \mathrm{H},=\mathrm{CH}-\mathrm{C}=\mathrm{O}), 2.06\left(3 \mathrm{H}, \mathrm{CH}_{3}\right)$.

Compound 2a: deep brown solid (yield: $90 \%), \mathrm{mp} 220^{\circ} \mathrm{C}$ IR $(\mathrm{KBr})\left(\mathrm{cm}^{-1}\right): \mathrm{v}: 3500-3195$ $\left(\mathrm{NH}_{2}\right), 2985-2879$ (aliphaticCHstr.), $1690(\mathrm{C}=\mathrm{O}), 1601(\mathrm{ArC}=\mathrm{C}), 1578(\mathrm{C}=\mathrm{N}), 1463(\mathrm{C}-\mathrm{H}$ bend); $1229(\mathrm{C}=\mathrm{S}), \mathrm{MS}(\mathrm{m} / \mathrm{z} \%): 258(\mathrm{M}+2,5.25 \%), 175(100 \%) ;{ }^{1} \mathrm{H}-\mathrm{NMR}\left(\mathrm{DMSO}_{6}\right) \delta$ : 7.45- $6.16(2 \mathrm{H}, \mathrm{Ar}), 5.92(1 \mathrm{H},-\mathrm{CH}-\mathrm{C}=\mathrm{N}), 4.12\left(2 \mathrm{H}, \mathrm{NH}_{2}\right), 2.1\left(3 \mathrm{H}, \mathrm{CH}_{3}\right)$.

Compound 2b: Yellow solid (yield: 90\%) mp above 300. IR (KBr) $\left(\mathrm{cm}^{-1}\right): \mathrm{v}: 3396(\mathrm{NH})$, 2985-2850 (aliphaticCHstr.), $1624(\mathrm{C}=\mathrm{N}), 1475(\mathrm{C}-\mathrm{H}$ bend), $1190(\mathrm{C}=\mathrm{S}), ; \mathrm{MS}(\mathrm{m} / \mathrm{z} \%): 57$ $(100 \%),{ }^{1} \mathrm{H}-\mathrm{NMR}\left(\mathrm{DMSO}_{6}\right)$ $): 1.24(1 \mathrm{H},-\mathrm{CH}=\mathrm{C}-), 7.31,8.22-7.95(3 \mathrm{H}, \mathrm{Ar}), 3.20(1 \mathrm{H}$, $\mathrm{SH}), 1.2\left(3 \mathrm{H}, \mathrm{CH}_{3}\right)$.

Compound 2c: Yellow solid (yield: $85 \%) \mathrm{mp} 280^{\circ} \mathrm{C}$, IK (KBr) $\left(\mathrm{cm}^{-1}\right)$ : v: $3370(\mathrm{OH}), 3032$ (ArCH), 2985-2879(aliphaticCHstr.),2570(SH), $1594(\mathrm{C}=\mathrm{N}), 1453(\mathrm{C}-\mathrm{H}$ bend). $1240(\mathrm{C}=\mathrm{S})$; MS (m/z \%): $186(100 \%),{ }^{1} \mathrm{H}-\mathrm{NMR}\left(\mathrm{DMSO}-\mathrm{d}_{6}\right) \delta: 7.44-6.82(8 \mathrm{H}, \mathrm{Ar}), 3.1\left(3 \mathrm{H}, \mathrm{CH}_{3}\right), 2.6$ $(1 \mathrm{H}, \mathrm{SH})$.

Compound 2d: Brown solid (yield: $82 \%) \mathrm{mp} 260^{\circ} \mathrm{C}$, IR $(\mathrm{KBr})\left(\mathrm{cm}^{-1}\right)$ : v: $3184(\mathrm{OH}-\mathrm{acid})$, $1725(\mathrm{C}=\mathrm{O}), 1595(\mathrm{C}=\mathrm{N}), 1215(\mathrm{C}=\mathrm{S}), \mathrm{MS}(\mathrm{m} / \mathrm{z} \%): 245(0.57 \%), 121(100 \%),{ }^{1} \mathrm{H}-\mathrm{NMR}$ $\left(\mathrm{DMSO}_{6} \mathrm{~d}_{6}\right) \delta: 12.66(1 \mathrm{H}, \mathrm{COOH}), 7.58-7.05(4 \mathrm{H}, \mathrm{Ar}), 6.9(1 \mathrm{H}, \mathrm{ArCH}=, 5.3(1 \mathrm{H}, \mathrm{CHC}=\mathrm{N}-$ ), $2.7(1 \mathrm{H}, \mathrm{NH})$.

Compound 2e: Brown solid (yield: $85 \%) \mathrm{mp} 298^{\circ} \mathrm{C}$, IR (KBr) $\left(\mathrm{cm}^{-1}\right)$ : v: $3280(\mathrm{NH}), 2985-2850$ (aliphaticCHstr.), 1600 ( $\mathrm{Ar} \mathrm{C}=\mathrm{C}), 1594(\mathrm{C}=\mathrm{N}), 1470(\mathrm{C}-\mathrm{H}$ bend), $1294(\mathrm{C}=\mathrm{S}), \mathrm{MS}(\mathrm{m} / \mathrm{z} \%)$ : $267(\mathrm{M}+1,10 \%), 64(100 \%),{ }^{1} \mathrm{H}-\mathrm{NMR} \quad\left(\mathrm{DMSO}_{6} \mathrm{~d}_{6}\right) \quad \delta: 9.02\left(\mathbb{N}_{\mathrm{N}}\right), 8.4-7.01 \quad(\mathrm{Ar}$ protons $), 5.1(1 \mathrm{H},=\mathrm{CH}-(\mathrm{C}=\mathrm{N}) \mathrm{N}) 2.06(1, \mathrm{H}, \mathrm{NH}), 1.9\left(3 \mathrm{H}, \mathrm{CH}_{3}\right)$. 


\section{Biological Activity}

Standard discs of Tetracycline (Antibacterial agent), amphotericin B (Antifungal agent) served as positive controls for antimicrobial activity but filter discs impregnated with $10 \mu \mathrm{L}$ of solvent (distilled water, chloroform, DMSO) were used as a negative control.

The agar used is Meuller-Hinton agar that is rigorously tested for composition and $\mathrm{pH}$. Further the depth of the agar in the plate is a factor to be considered in the disc diffusion method. This method is well documented and standard zones of inhibition have been determined for susceptible and resistant values.

Blank paper disks (Schleicher and Schuell, Spain) with a diameter of $8.0 \mathrm{~mm}$ were impregnated $10 \mu$ of tested concentration of the stock solutions. When a filter paper disc impregnated with a tested chemical is placed on agar the chemical will diffuse from the disc into the agar. This diffusion will place the chemical in the agar only around the disc. The solubility of the chemical and its molecular size will determine the size of the area of chemical infiltration around the disc. If an organism is placed on the agar it will not grow in the area around the disc if it is susceptible to the chemical. This area of no growth around the disc is known as a "Zone of inhibition" or "clear zone".

Table 1. Antifungal activity data and antibacterial activity.

\begin{tabular}{|c|c|c|c|c|c|}
\hline \multirow{2}{*}{\multicolumn{2}{|c|}{ Compound No. }} & \multicolumn{2}{|c|}{ Mic against Fungi, $\mu \mathrm{gmL}^{-1}$} & \multicolumn{2}{|c|}{ Mic against bacteria, $\mu \mathrm{gmL}^{-1}$} \\
\hline & & Af & $\mathrm{Ca}$ & Ec & $\mathrm{Sa}$ \\
\hline \multirow{12}{*}{ 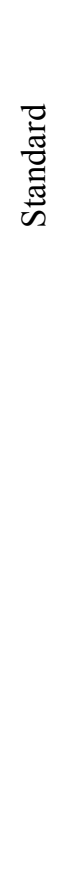 } & $\begin{array}{l}\text { Tetracycline } \\
\text { antibacterial agent }\end{array}$ & - & - & 33 & 32 \\
\hline & $\begin{array}{l}\text { Amphotericin } B \\
\text { antifungal agent }\end{array}$ & 18 & 20 & - & - \\
\hline & $1 \mathbf{a}$ & - & 18 & 10 & 10 \\
\hline & $1 b$ & - & - & - & - \\
\hline & $1 \mathrm{c}$ & - & - & 9 & 12 \\
\hline & 1d & - & - & 12 & 12 \\
\hline & $1 \mathrm{e}$ & 48 (US) & 33 & 52 & 60 \\
\hline & $2 \mathbf{a}$ & - & - & 14 & 14 \\
\hline & $\mathbf{2 b}$ & 13 & 12 & 13 & 13 \\
\hline & $2 \mathrm{c}$ & 14 & 13 & 15 & 16 \\
\hline & 2d & 11 & 13 & 14 & 15 \\
\hline & $2 \mathrm{e}$ & 13 & 13 & 17 & 19 \\
\hline
\end{tabular}

Af: Aspergillus flavus, Ca-Candida albicans, Ec - Escherichia coli, Sa-Staphylococcus aureus , US: Unsporulated area. 


\section{Antitumour Screening}

Chemotherapy is a major therapeutic approach for the treatment of both localized and metastasized cancers. In the present work selected compounds related to coumarin derivatives and comarin quinolinyl mercaptotriazoles were evaluated as inhibitors of the growth of breast cancer cell line in comparison to the known anticancer drug: doxorubicin as a trial to get more effective and les toxic agent.
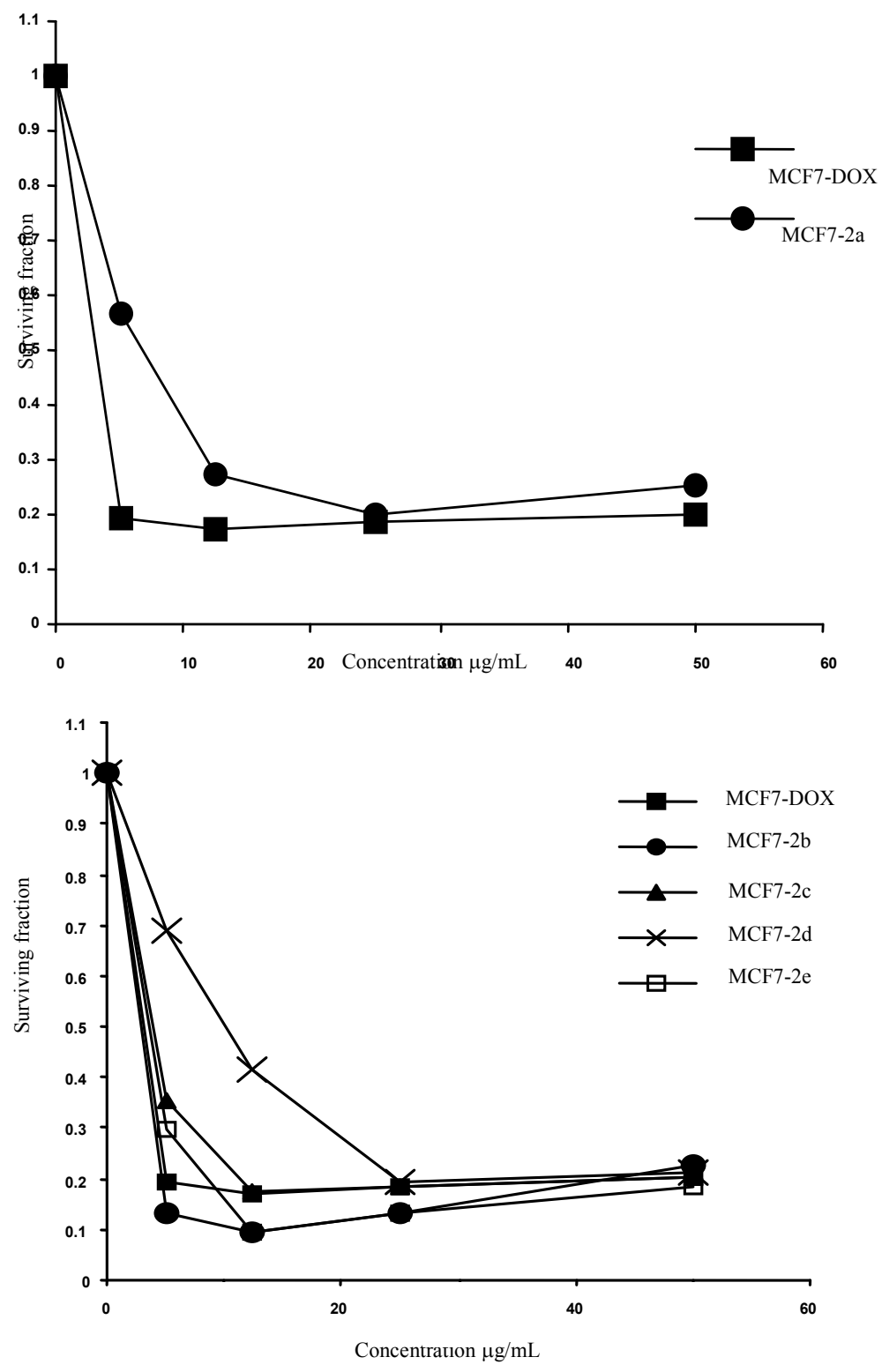

Figure (1): Drug cytotoxicity of product $\mathbf{2 a}, \mathbf{2 b}, \mathbf{2 c}, \mathbf{2 d}$ and $2 \mathrm{e}$ compared to doxorubicin. 
Preliminary experiments were done using the human tumor cell line to identify the potential toxicity of five selected newly synthesized compounds (2a-e) (Figure 1) in comparison to the known anticancer drug doxorubicin by SRB using the method Skehan et al. ${ }^{23}$.

- Cells were plated in 96-multiwell plate $\left(10^{4}\right.$ cells/well) for 24 hours before treatment with compounds to allow attachment of cell to the wall of the plate.

- Different concentration of the compound under test $(0,1,2.5,5$ and $10 \mu \mathrm{g} / \mathrm{mL})$ were added to the cell monolayer triplicate wells prepared for each individual does.

- Monolayer cells were incubated with the compounds for 48 hours at $37{ }^{\circ} \mathrm{C}$ and atmosphere of $5 \% \mathrm{CO}_{2}$.

- After 48hours, cells were fixed, washed and stained with Sulfo-Rhodamine- $\beta$ stain.

- Excess stain was washed with acetic acid and attached stain was recovered with Tris EDTA buffer.

- Color intensity was measured in an ELISA reader.

- The relation between surviving fraction and drug concentration is plotted to get the survival curve of each tumour cell line after the specified compound.

Table 2. Effect of some selected newly synthesized compounds on breast cancer cell line.

\begin{tabular}{cc}
\hline Compound & $\mathrm{IC}_{50}$ \\
\hline Doxorubicin & $4.17 \mu \mathrm{g} / \mathrm{mL}$ \\
$\mathbf{2 a}$ & $8.85 \mu \mathrm{g} / \mathrm{mL}$ \\
\hline
\end{tabular}

\section{Results and Discussion}

Condensation of ethylacetoacetate with different phenols in absent of solvent and in present of montmorillonite clays which have been used as efficient catalysts for a variety of organic reactions ${ }^{20}$ derivatives of coumarin which have been considered an environmentally friendly procedure via pechmann reaction. In the presence of montmorillonite clays ${ }^{21}$, several phenols and ethyl acetoacetate were heated in the absence of solvent to give the corresponding coumarins in good yields (1a-e) which on reaction with thiosemicrbazide in anhydrous pyridine yielded quinolinyl mercapto triazole derivatives (2a-e). The synthetic pathway is given in Scheme 1.

From the experimental results, it can be proved that phenols having electron donating substituents in the position meta to the phenol hydroxyl group promote the condensation. The $+E$ effects of these substituents support formation of the reactive polarized carbonation in the ortho position. An alkyl group is not strong enough to furnish the activation needed and thus gives a low yield (1a) in contrast, electron-withdrawing groups inhibit the reaction.

The following table showing the same effect but with different $\mathrm{IC}_{50}$ for standard Doxourubicin: 


\begin{tabular}{cc}
\hline Compound & $\mathrm{IC}_{50}$ \\
\hline Doxorubicin & $3.13 \mu \mathrm{g} / \mathrm{mL}$ \\
$\mathbf{2 b}$ & $2.79 \mu \mathrm{g} / \mathrm{mL}$ \\
$\mathbf{2 c}$ & $3.89 \mu \mathrm{g} / \mathrm{mL}$ \\
$\mathbf{2 d}$ & $10.1 \mu \mathrm{g} / \mathrm{mL}$ \\
$\mathbf{2 e}$ & $3.43 \mu \mathrm{g} / \mathrm{mL}$ \\
\hline$I C_{50}:$ Dose of the compound which \\
reduces survival to $50 \%$. \\
\hline
\end{tabular}

\section{Conclusion}

In this work, it was of interest to synthesize new series of some novel coumarin quinolinyl mercapto triazole. First, the synthesis of coumarin derivatives (1a-e) were dependent at the use of environmentally friendly procedure by montmorillonite clay which have been used as efficient catalysts and are inexpensive non toxic powders. Second the series compounds of quinolinyl mercaptotriazole (2a-e) were found exhibiting a highly biological and antitumor effect.

The antitumor activity results indicated that all the second five derivatives (2a-e) showed antitumor activity against the tested breast cancer cell line but with varying intensities in comparison to the known anticancer drug: doxorubicin. Moreover compound 2e showed the highest cytotoxic activity $\left(\mathrm{IC}_{50}\right.$ equal $\left.3.43 \mu / \mathrm{mL}\right)$ which was more effective than Doxorubicin $\left(\mathrm{IC}_{50}\right.$ equal $\left.3.13 \mu / \mathrm{mL}\right)$.

\section{References}

1. Zhang Y, Zhong Qiao R, Feng Dai C, Fei Xu P and Zhang Y Z, Chine Chem Lett., 2002, 13, 287-289.

2. Demirbas A, Sahin D, Demirbas N and Karaoglu S A, Eur J Med Chem., 2009, 44, 2896-2903.

3. Bayrak H, Demirbas A, Karaoglu A S and Demirbas N, Eur J Med Chem., 2009, 44, 1057-1066

4. Eswaran S, Adhikari A V and Shetty N S, Eur J Med Chem., 2009, 44, 4637-4647.

5. Bayrak H, Demirbas N and Karaoglu S A, Eur J Med Chem., 2009, 44. 4362-4366.

6. Isloor A M, Kalluraya B and Shetty P, Eur J Med Chem., 2009, 44, 3784.

7. Navidpour L, Shafaroodi H, Abdi K, Amini M, Gharemani M H, Dehpour A R and Shafiee A, Bioorg Med Chem., 2006, 14, 2507-2517.

8. Al-Deeb O A, Al-Omar M A, El-Brollosy N R, Habib E E, Ibrhaim T M and El-Eman A A, Arzneim-Forsch/Drug Res., 2006, 56, 40-47.

9. Kumar H, Daved S A, Khan S A and Amir M, Eur J Med Chem., 2008, 43, 2688-2698.

10. Al-Saud Y A and Al-Masoudi N A, J Braz Chem Soc., 2003, 14, 790-796.

11. El Ashry E S H, Kassem A A, Abdel-Hamid H, Louis F F, Khattab Sh A N and Aouad M R, Arkivoc., 2006, X.V, 119-132.

12. Al-Omar M A, Molecules., 2010, 15, 502-514.

13. Sethna S and Phadka R, Org Reat., 1953, 7, 1.

14. Johnson J R, Org React., 1942, 1, 210.

15. Jones G, Org React., 1967, 15, 204.

16. Brufola G, Fringuelli F, Piermatti O and Pizzo F, Heterocycl., 1996, 43, 1257.

17. Shirner R L, Org React., 1942, 1, 1 .

18. Narasimhan N S, Mali R S and Barve M V, Synthesis, 1979, 906.

19. Mali R.S, Yeola S N and Kulkarni B K, Indian J Chem., 1983, 22B, 352. 
20. $\quad$ Li T S and Din T S, Younji Huaxue, 1996, 16, 385.

21. Li T S, Yang Y T and Li Y L, J Chem Res (S), 1993, 28; Li, T S, Li H Z, Guo J L, Jin Synt Commun., 1996, 26, 2497; Li T S, Li J T and Li H Z, J Chem Res (S), 1997, 26; Li T.S and Li S.H, Synth Commun., 1997, 27, 2299; Zhang Z H, Li T S and Fu C G, J Chem Res (S), 1997, 174; Li T S, Zhang Z H and Fu C G, Tetrahedron Lett., 1997, 38, 3285; (g) Li A X, Li T S and Ding T H, Chem Commun., 1997, 1389.

22. $\quad$ Li T S, Zhang Z H, Yeng F and Fu C G, J Chem Research (S), 1998, 38-39.

23. Storeng P and Skehan R, J Natl Cancer Inst., 1990, 82, 1107-1112. 


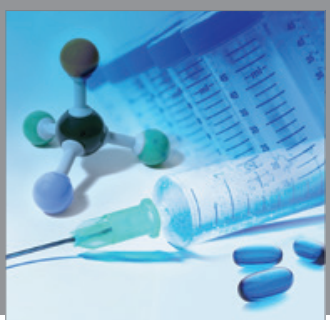

International Journal of

Medicinal Chemistry

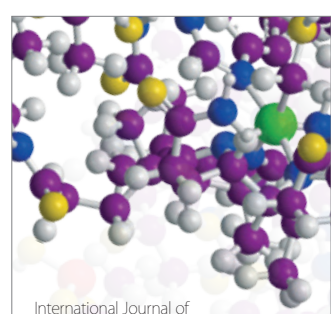

Carbohydrate Chemistry

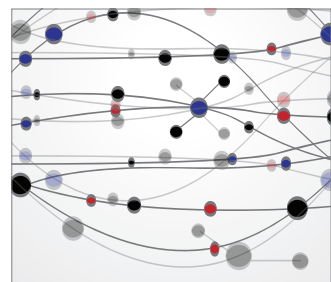

The Scientific World Journal
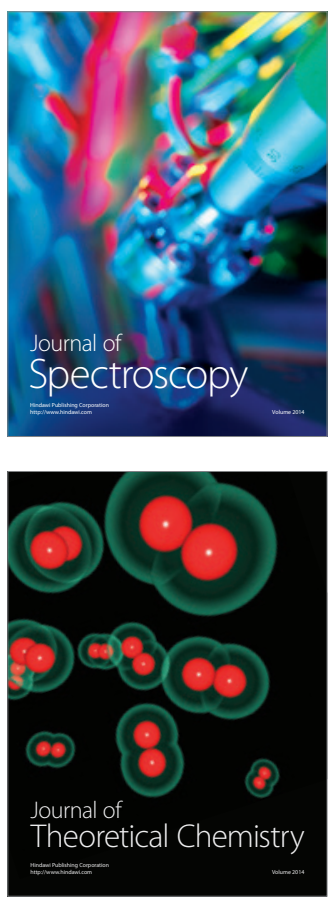
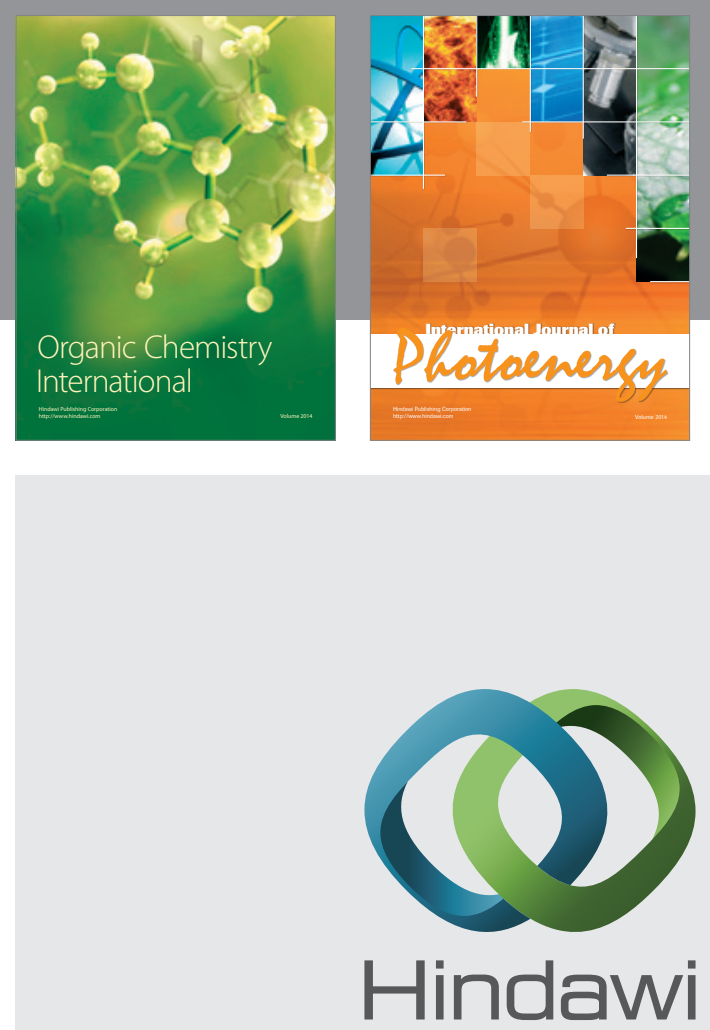

Submit your manuscripts at

http://www.hindawi.com
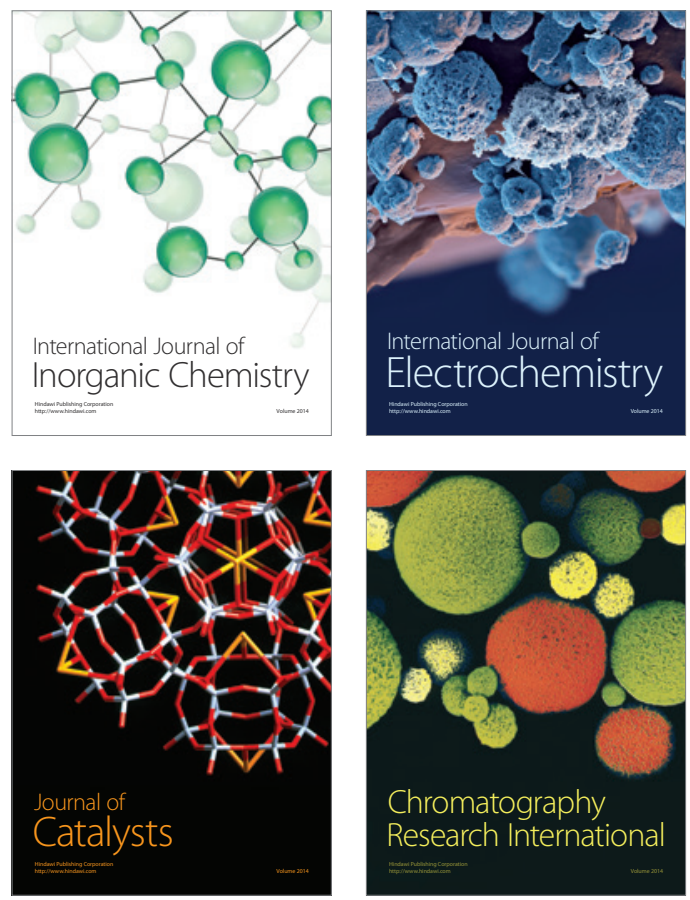
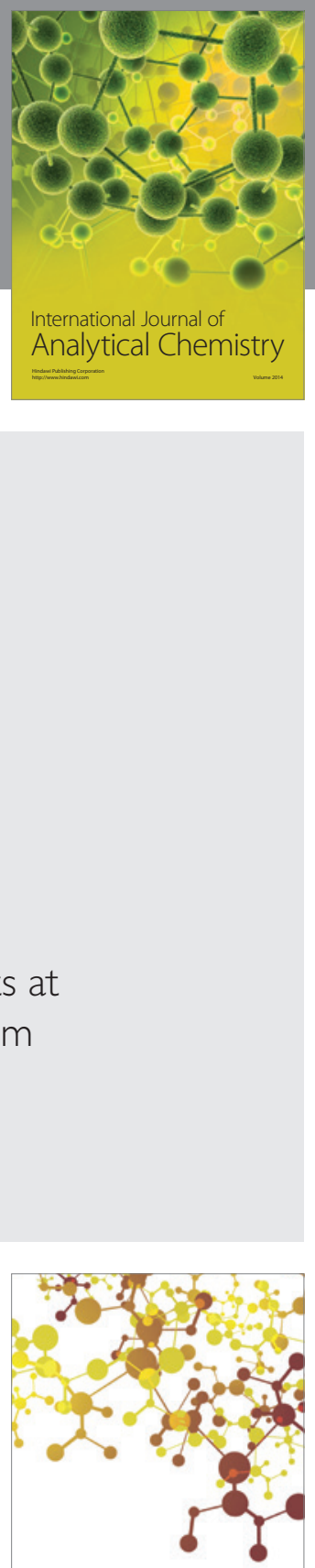

Journal of

Applied Chemistry
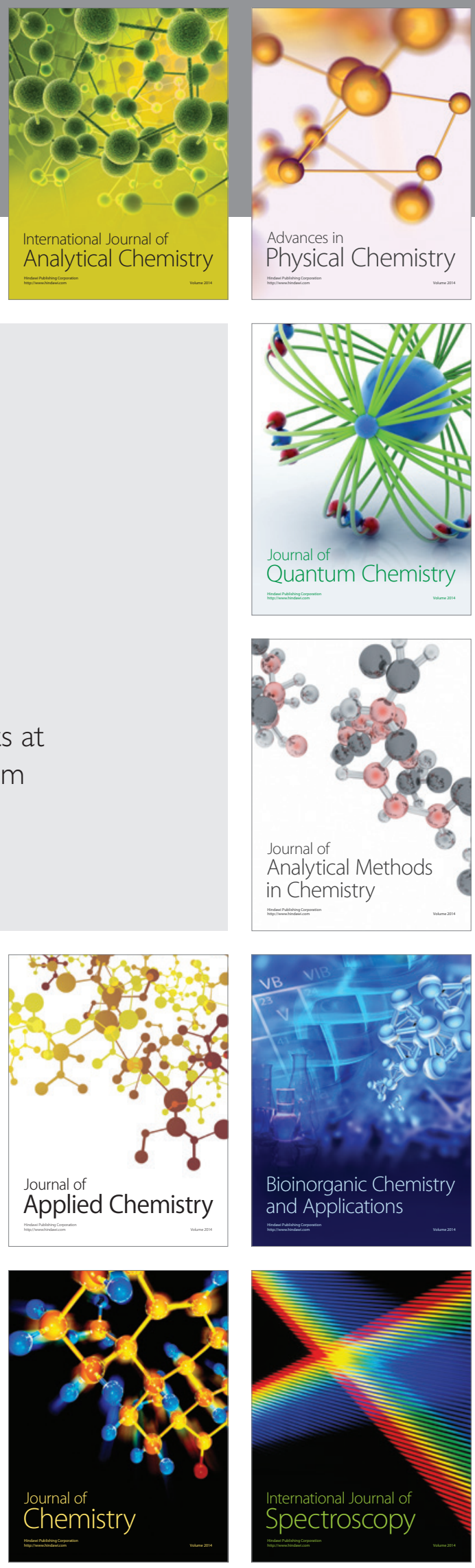